\title{
Karyotypic diversity among three species of the genus Astyanax (Characiformes: Characidae)
}

\author{
P. B. Nishiyama ${ }^{*}$, M. M. R. Vieira ${ }^{b}$, F. E. Porto, L. A. Borin', \\ A. L. B. Portela-Castro ${ }^{c}$ and I. C. M. Santos ${ }^{c}$ \\ anstituto Multidisciplinar em Saúde, Universidade Federal da Bahia - UFBA, Campus Anísio Teixeira, \\ Rua Rio de Contas, 58, quadra 17, Candeias, CEP 45029-094, Vitória da Conquista, BA, Brazil

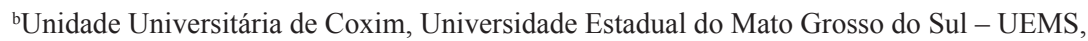 \\ Rua General Mendes de Moraes, 370, Jardim Aeroporto, CEP 79400-000, Coxim, MS, Brazil \\ 'Departamento de Biotecnologia, Genética e Biologia Celular, Universidade Estadual de Maringá - UEM, \\ Av. Colombo, 5790, Jardim Universitário, CEP 87020-900, Maringá, PR, Brazil \\ *e-mail: patriciabelini@globo.com
}

Received: August 18, 2014 - Accepted: February 24, 2015 - Distributed: May 31, 2016

(With 3 Figures)

\begin{abstract}
The group Incertae sedis within the Characidae family currently includes 88 genera, previously included in the subfamily Tetragonopterinae. Among them is the genus Astyanax comprising a group of species with similar morphology and widely distributed in the Neotropics. Thus, the present study aimed to analyze the karyotype diversity in Astyanax species from different watersheds by conventional Giemsa staining, C-banding and fluorescence in situ hybridization (FISH rDNA 18S) probe.specimens of Astyanax aff. paranae belonging to the "scabripinnis complex", Astyanax asunsionensis and Astyanax aff. bimaculatus were analyzed". Two sympatric karyomorphs were observed in Astyanax. aff paranae, one of them having $2 n=48$ andthe other one with $2 n=50$ chromosomes. Other population of this same species also presented $2 \mathrm{n}=50$ chromosomes, but differing in the karyotype formula and with macro supernumerary chromosome found in $100 \%$ of the cells in about $80 \%$ of females analyzed. Two population of $A$. asuncionensis and one population of Astyanax. aff. bimaculatus, also showed a diploid number of 50 chromosomes, but also differing in their karyotype formulas. Therefore, A. asuncionensis was also characterized by intraspecific chromosome diversity. The C-banding analysis was able to demonstrate a distinctable to demonstrate a distinct pattern of heterochromatin differing A. asuncionensis from Astyanax aff. paranae and Astyanax aff. bimaculatus. The supernumerary chromosome of Astyanax aff. paranae proved completely heterochromatic. Only Astyanax.aff. bimaculatus multiple showed multiple sites of nucleolar organizing regions. The other species were characterized by having a simple system of NOR. These data contributes to the know ledge of the existing biodiversity in our fish fauna, here highlighted by the inter- and intraspecific chromosomal diversity in the genus Astyanax.
\end{abstract}

Keywords: cytogenetics, biodiversity, B chromosomes, C-bands, NORs.

\section{Diversidade Cariotípica entre três espécies do gênero Astyanax (Characiformes, Characidae)}

\section{Resumo}

O grupo Incertae sedis, dentro da família Characidae inclui atualmente 88 gêneros, anteriormente incluídos na subfamília Tetragonopterinae. Dentre eles encontra-se o gênero Astyanax que compreende um grupo de espécies com morfologia similar e com ampla distribuição na região Neotropical. Assim, o presente estudo teve como objetivo analisar a diversidade cariotípica em espécies de Astyanax de diferentes bacias hidrográficas, através da coloração convencional com Giemsa, bandeamento C e hibridização fluorescente in situ (FISH com rDNA 18S). Exemplares de Astyanax aff. paranae, pertencentes ao "complexo scabripinnis"; Astyanax asunsionensise Astyanax aff. bimaculatus foram analisados. Dois cariomorfos foram observados em $A$. aff. paranae, um deles com $2 \mathrm{n}=48$ cromossomos e outro $\operatorname{com} 2 \mathrm{n}=50$ cromossomos. Outra população apresentou $2 \mathrm{n}=50$ cromossomos, ambas diferindo na fórmula cariotípica e um cromossomo supranumerário encontrado em $100 \%$ das células, em aproximadamente $80 \%$ das fêmeas analisadas. Populações de A.asunsionensis e uma população de Astyanax aff. Bimaculatus também mostraram número diplóide de 50 cromossomos, mas diferindo em suas fórmulas cariotípicas. Portanto, A. asuncionensis foi também caracterizado por uma diversidade cariotípica intraespecífica. As análises de bandeamento $\mathrm{C}$ foi capaz de demonstrar um padrão distinto de heterocromatina, diferindo A. asuncionensis de $A$. aff. paranae e $A$. aff. bimaculatus. $\mathrm{O}$ cromossomo supranumerário 
de Astyanax aff. paranae mostrou-se completamente heterocromático. Apenas Astyanax aff. bimaculatus mostrou múltiplos sítios de regiões organizadoras de nucléolo(NORs). As outras espécies foram caraterizadas por apresentar um sistema simples de NOR. Estes dados contribuem para o conhecimento da existência de biodiversidade em nossa fauna de peixes, aqui em destaque pela diversidade cromossômica inter e intraespecífica no gênero Astyanax.

Palavras-chave: citogenética, biodiversidade, cromossomos B, bandas C, NORs.

\section{Introduction}

Teleost fishes, which make up about half of the species of vertebrates have an incredible level of biodiversity (Volff, 2005). According to Nelson (2006), they constitute a very favorable group for evolutionary studies, in view of their basal position in the phylogeny of vertebrates, with a large number of species dispersed in the Neotropical region. Characidae is one of the most complex families within Characiformes fishes, presenting a diverse range of forms, which allowed them to occupy many different habitats, with diversification of food processes and reproductive strategies (Graça and Pavanelli, 2007).However, for Lucena (1993), these characteristics have hampered the classification of its copies and the of kinship relations with other Characiformes families.

Given the complexity of characins, 620 species are included within an Incertae Sedis group, including Astyanax representatives (Lima et al., 2003). Studies by Mirande (2010) the principal objective of the proposed taxonomic nomenclature is to classify members of the Characidae in monophyletic units, this works includes the genus Astyanax asunsionensis in Clade Astyanax. Cytogenetic studies performed by Moreira-Filho and Bertollo (1991), particularly in A. scabripinnis revealed a group of species that were named "scabripinnis complex". Graça and Pavanelli, (2007), considered Astyanax. aff. paranae as part of this complex.

Astyanax have presented an extensive diversity in the chromosome number and karyotype formula, both intra- and interspecifically, besides the occurrence of $\mathrm{B}$ chromosomes and natural polyploidy for some populations (Malacrida et al., 2003; Gross et al., 2004; Kantek et al., 2007; Peres et al., 2009; Santos et al., 2012).

The present study aimed to analyse different populations of three Astyanax species using conventional and molecular cytogenetic procedures, order to contribute to the knowledge biodiversity in this fish group.

\section{Material and Methods}

Seventy-one specimens belonging to three species of the genus Astyanax were colleted. Two populations of Astyanax aff. paranae from Paraná River basin, Maringá/ PR region: Andirá stream - $23^{\circ} 22^{\prime} 02^{\prime \prime} \mathrm{S}, 52^{\circ} 11^{\prime} 42^{\prime \prime} \mathrm{W}$ (4 males and 2 females) and Itiz stream $-23^{\circ} 32^{\prime} 11.2^{\prime \prime} \mathrm{S}$, $51^{\circ} 46^{\prime} 59^{\prime \prime} \mathrm{W}$ ( 5 males and 8 females). One population of Astyanax aff. bimaculatus from Pardo River Basin,Vitória da Conquista/BA region: Bateias lagoon - 14'51'26”'S, $40^{\circ} 52^{\prime} 13^{\prime \prime} \mathrm{W}$ ( 8 males and 12 females). Two populations of A.asuncionensis from upper Paraguay River basin
Coxim/MS region: Onça stream- $18^{\circ} 30^{\prime} \mathrm{S}, 5^{\circ} 39^{\prime} \mathrm{W}(9$ males and 6 females) and Criminoso stream - 18 $29^{\prime} 21^{\prime \prime}$, $54^{\circ} 45^{\prime} 13,9^{\prime \prime} \mathrm{W}$ (10 males and 7 females). The specimens were deposited in the collection of Laboratory of the Zoology Universidade Federal da Bahia, Vitória da Conquista/BA.

Mitotic chromosomes were performed according to the technique "air drying" as modified for fish by Bertollo et al. (1978). The prepared slides were stained with Giemsa for conventional studies, to determine the number and morphology of chromosomes. The constitutive heterochromatin (C-banding) was performed according to Sumner (1972), with some minor adjustments (Lui et al., 2009). The nucleolar organizing regions (NORs sites) were identified by fluorescence in situ hybridization (FISH), with rDNA 18S probe, according to Pinkel et al. (1986). The chromosomes were classified as metacentric (m), submetacentric (sm) subtelocentric (st) and acrocentric (a) according to Levan et al. (1964).

\section{Results}

\subsection{Astyanax aff. paranae}

Two populations of this species were analyzed in this study, one Andirá stream (A population) and another from Itiz stream (B Population). However, two distinct karyotypes were identified in the A population, one with $2 \mathrm{n}=48$ chromosomes, $14 \mathrm{~m}+18 \mathrm{sm}+6$ st e $10 \mathrm{a}$ (Figure 1a); and the other with $2 \mathrm{n}=50$ chromosomes, $8 \mathrm{~m}+22 \mathrm{sm}$ $+6 s t+14 \mathrm{a}$ (Figure 1b). B Population showed $2 \mathrm{n}=50$ chromosomes, with $12 \mathrm{~m}+16 \mathrm{sm}+6 \mathrm{st}+16 \mathrm{a}$, and with also a macro supernumerary chromosome, similar in size to the first pair of metacentric chromosome found in $100 \%$ of the cells of about $80 \%$ of the females analized (Figure 1c).

All specimens of Astyanax aff.paranae showed a discrete localization of heterochromatin in the centromeric region of the chromosomes, plus some pairs with conspicuous telomeric blocks. The supernumerary chromosome of the population from Itiz stream was completely heterochromatic (Figure 2a-c).

NORs were present in the short arm of only one submetacentric pair, with eventual size polymorphism between the homologous (Figure 3a-c).

\subsection{Astyanaxaff.bimaculatus}

Astyanax aff. bimaculatus from Bateias Lagoon showed $2 \mathrm{n}=50$ chromosomes, with $10 \mathrm{~m}+24 \mathrm{sm}+8 \mathrm{st}+8 \mathrm{a}$ (Figure 1d). C-bands were also discrete and with a preferential pericentromeric distribution, although with interstitial markings in some chromosomes of the complement (Figure 2d). A system of multiple-NOR, comprising two 




Figure 1. Karyotype of the Astyanax aff. paranae, Andirá stream: (a) specimens with $2 \mathrm{n}=48$ chromosomes and (b) specimens with $2 \mathrm{n}=50$ chormosomes; (c) Astyanax aff. paranae, Itiz stream: $2 \mathrm{n}=50$ chromosomes plus a macro supernumerary metacentric chromosome; (d) Astyanax aff. bimaculatus from Bateias Lagoon: 2n=50chromosomes; (e) Astyanax asuncionensis, Criminoso stream: $2 \mathrm{n}=50$ chromosomes and (f) Astyanax asuncionensis, from Onça stream: $2 \mathrm{n}=50$ chromosomes.

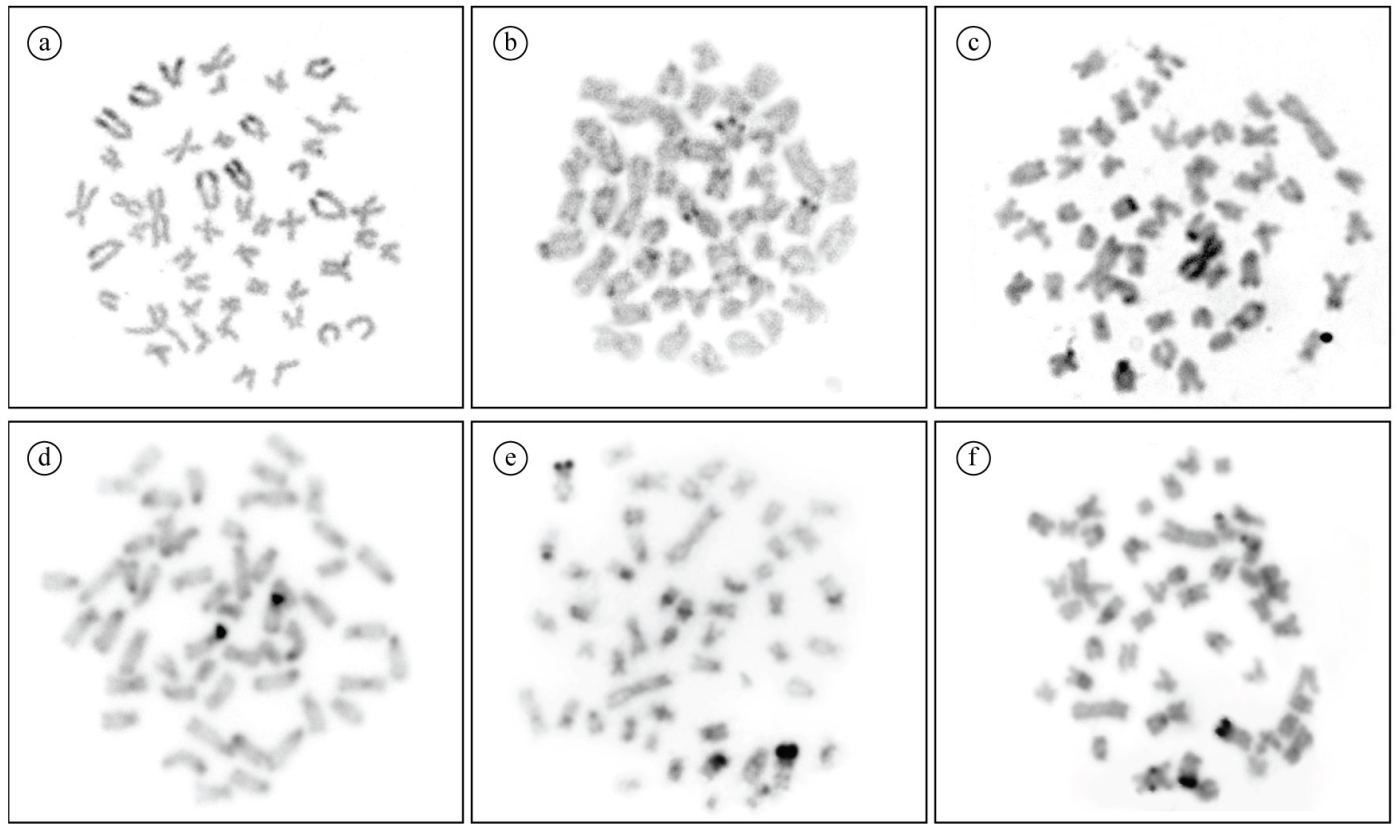

Figure 2. C-banded metaphases of (a) Astyanax aff. paranae $(2 \mathrm{n}=48)$ from Andirá stream, (b) Astyanax aff. paranae $(2 \mathrm{n}=50)$ from Andirá stream, (c) Astyanax aff. paranae from Itiz stream, (d) Astyanax aff. bimaculatus from Bateias Lagoon, (e) Astyanax assuncionensis from Criminoso stream, (f) Astyanax asuncionensis from Onça stream. 
pairs of submetacentric chromosomes was identified for this species (Figure 3c).

\subsection{Astyanaxasuncionensis}

The two populations of A.asuncionensis, from Criminoso stream (A population) and Onça stream (B population) showed $2 n=50$ chromosomes, but with variations in karyotype formulas. Population Ahighlighted $8 \mathrm{~m}+30 \mathrm{sm}$ $+6 \mathrm{st}+6 \mathrm{a}$ (Figure 1e) and population B showed $6 \mathrm{~m}+$ $24 \mathrm{SM}+10 \mathrm{st}+10 \mathrm{a}$ (Figure 1f). The general distribution pattern of the constitutive heterochromatin was similar in the two populations with pericentromeric and/or interstitial blocks in some chromosomes pairs, besides conspicuous terminal blocks coinciding with NORs (Figure 2e, f). In both populations only a pair of submetacentric pair evidenced telomeric NORs on the short arms (Figure 3e, f).

\section{Discussion}

Astyanax aff.paranae, considered as part of the "scabripinnis complex" (Graça and Pavanelli, 2007), highlighted two sympatric karyomorphs in the Andirá stream (populations A and B) showing distinct diploid numbers and karyotypic formulas. In addition, specimens from Itiz stream, although showing a relative similarity with karyomorph B, display a macro supernumerary chromosome characteristic for this population. Modifications in the diploid numbers and in the karyotypic formulas indicate that distinct rearrangements took place in the chromosome evolution of these fishes, such as Robertsonian rearrangements and that ones modifying the centromere position. It is outstanding that the subtelocentric chromosomes were the most conservative ones, keeping the same number in most species now analyzed. Fernandes and Martins-Santos (2005) analyzing A. scabripinnis from Tatupeba stream, also highlight the role of Robertsonian rearrangements, such as centric fusions, in the karyotype differentiation of this species, where specimens with $2 n=46,48$ and 50 chromosomes were found in sympatry indicating that in this locality three distinct species. appear to coexist. Similarly the two karyomorphs from Andirá stream indicate the coexistence of two probable cryptic species which, together with the population of Itiz stream and compared with studies Vicari et al. (2008), supporta likely species complex in Astyanax aff. paranae. According to these authors, the number of the species in this complex is subestimated. As a whole, the available data indicate that the karyotype evolution in this fish group is very dynamic and goes beyond the 'simple' accumulation of chromosomal rearrangements (Santos et al., 2012).

A large supernumerary or B chromosome, similar to that found in the population from Itiz stream, has been observed in several populations of $A$. scabripinnis (Néo et al., 2000; Maistro et al., 2001; Ferro et al., 2003; Fernandes and Martins-Santos, 2005; Santos et al., 2012). The first approach on the probable origin of this chromosome was performed


Figure 3. FISH with rDNA $18 \mathrm{~S}$ probe in Astyanax aff. paranae, Andirá stream $(2 \mathrm{n}=48)$; Astyanax aff. paranae from Andirá stream $(2 \mathrm{n}=50)$; Astyanax aff. paranae from Itiz stream; Astyanax aff. bimaculatus from Bateias Lagoon; Astyanax asuncionensis from Criminoso stream; Astyanax asuncionensis from Onça stream. Chromosome pairs bearing NOR by arrows. 
by Salvador and Moreira-Filho (1992), who considered that a non-disjunction, followed by heterochromatinization, could be associated with its emergence. However strong evidence that this supernumerary is an isochromosome was given by some additional mitotic and meiotic studies, which also indicated that its heterochromatic nature is related with the amplification and dispersion of highly repetitive sequences (Mestriner et al., 2000; Moreira-Filho et al., 2004; Vicari et al., 2011).

Astyanax asuncionensis and Astyanax aff. bimaculatus showed the same diploid number $(2 \mathrm{n}=50)$ but with differences in the karyotype formulas, probably due to rearrangements such as pericentric inversions. This last group, unlike the "scabripinnis group", has shown a constancy in the diploid number (Domingues et al., 2007; Pamponet et al., 2008; Ferreira Neto et al., 2009; Kavalco et al., 2011; Pacheco et al., 2011; Peres et al., 2011; Martinez et al., 2012), indicating an evolutionary karyotype pattern relatively more conserved than that of the "scabripinnis complex". In turn, the distinct karyotypes presented by the two populations of $A$. asuncionensis also show the occurrence of two karyomorphs and a probable "asuncionensis complex." Reinforcing this hypothesis, Desordi et al., (2011) found that populations of $A$. asuncionensis from Paraguay basin although inhabiting the same river system, show diversity in the population structure and in morphological features, indicating to be very different from each other.

Astyanax has also shown a wide variation in the of distribution of the constitutive heterochromatin in the chromosomes. While the "scabripinnis complex" has been characterized by a preferential centromeric and telomeric pattern of C-bands (Fernandes and Martins-Santos, 2005; Souza et al., 2007; Santos et al., 2012), the "bimaculatus group" has shown mainly interstitial heterochromatic blocks on the chromosomes (Domingues et al., 2007; Hashimoto et al., 2008; Ferreira Neto et al., 2009; Kavalco et al., 2011). The species now analyzed show that the distribution of heterochromatin falls, in general, among the above cases. Notably, all species showed C-positive bands in the centromeric and telomeric regions, in addition to some interstitial markings, with very conspicuous C-bands in some chromosome pairs. However, A. asuncionensis was the species with more evident interstitial heterochromatic regions, thus in this way differing from the pattern showed by Astyanax aff. paranae and Astyanax aff. bimaculatus.

As occur with C-bands, the genus Astyanax also shows distinct patterns in relation to NORs, with single and multiple systems and with both intra- and inter-specific variations in number and locations on the chromosomes (Kavalco and Moreira-Filho, 2003; Pazza et al., 2006; Capistano et al., 2008; Kavalco et al., 2011). In this study a multiple marking system was only found in Astyanax aff. bimaculatus. The other species showed only one pair of submetacentric chromosomes with NOR sites on the short arms. In this sense, $A$. aff. bimaculatus showed a divergent karyotype concerning to these chromosomal markers in comparison to the other species investigated.
The data obtained contribute to the knowledge of the existing biodiversity in the genus Astyanax, here evidenced by chromosomal characteristics of the species studied. In addition to evidence some aspects on the chromosome evolution in this fish group, indications about possible complexes of species in Astyanax aff. paranae and A. asuncionensis were also obtained. The biodiversity in Astyanax may be related to the biological characteristics of these fishes. Indeed, the possibility in forming small populations can favor the fixation of chromosome changes, both in the macro- as in the microstructure of the chromosomes.

\section{Acknowledgements}

The authors thank CNPq for financial support and Dr. Weferson Junio da Graça (UEM) for species identification.

\section{References}

BERTOLLO, L.A.C., TAKAHASHI, C.S. and MOREIRAFILHO, O., 1978. Cytotaxonomic considerations on Hoplias lacerdae (Pisces, Erythrinidae). Brazilian Journal of Genetics, vol. 1, pp. 103-120.

CAPISTANO, T.G., PORTELA-CASTRO, A.L.B. and JULIOJUNIOR, H.F., 2008. Chromosome divergence and NOR polymorphism in Bryconamericus aff. iheringii (Teleostei, Characidae) in the hydrographic systems of the Paranapanema and Ivaí Rivers, Paraná, Brazil. Genetics and Molecular Biology, vol. 31, no. 1 (Suppl), pp. 203-207.

DESORDI, R., REIS, D.G.S., KAVALKO, K.F. and PAZZA, R., 2011. Variabilidade morfológica e estruturação populacional de lambaris do grupo Astyanax aff. bimaculatus (Teleostei, Characiformes). Evolução e Conservação da Biodiversidade, vol. 2, pp. 73-78.

DOMINGUES, M.S., VICARI, M.R., ABILHOA, V., WANSER, J.P., CESTARI, M.M., BERTOLLO, L.A.C., ALMEIDA, M.C. and ARTONI, R.F., 2007. Cytogenetic and comparative morphology of two allopatric populations of Astyanax altiparanae Garutti \& Britski, 2000 (Teleostei: Characidae) from upper rio Paraná basin. Neotropical Ichthyology, vol. 51, no. 1, pp. 37-44.

FERNANDES, C.A. and MARTINS-SANTOS, I.C., 2005. Sympatric occurence of three cytotypes and four morphological types of B chromosomes in Astyanax scabripinnis (Pisces, Characiformes) in the river Ivaí basin, state Paraná, Brasil. Genetica, vol. 124, pp. 301-306.

FERREIRA NETO, M.F., VICARI, M.R., CAMARGO, E.F., ARTONI, R.F. and MOREIRA-FILHO, O., 2009. Comparative cytogenetics among populations of Astyanax altiparanae (Characiformes, Characidae, Incertae sedis). Genetics and Molecular Biology, vol. 32, no. 4, pp. 792-796. http://dx.doi.org/10.1590/ S1415-47572009005000078. PMid:21637456.

FERRO, D.A.M., MOREIRA-FILHO, O. and BERTOLLO, L.A.C., 2003. B Chromosome polymorphism in the fish, Astyanax scabripinnis. Genetica, vol. 119, no. 2, pp. 147-153. http://dx.doi. org/10.1023/A:1026086501252. PMid:14620954.

GRAÇA, W.J. and PAVANELLI, C.S., 2007. Peixes da planície de inundação do Alto Rio Paraná e áreas adjacentes. Maringá: Eduem. 241 p. 
GROSS, M.C., SCHNEIDER, C.H., MATIELLO, M.C.A., LEITE, M.L., BERTOLLO, L.A.C. and ARTONI, R.F., 2004. Population structure, fluctuating asymmetry and genetic variability in an endemic and highly isolated Astyanax fish population (Characidae). Genetics and Molecular Biology, vol. 27, no. 4, pp. 529-535. http://dx.doi.org/10.1590/S1415-47572004000400011.

HASHIMOTO, D.T., GONÇALVES, V.R., BORTOLOZZI, J., FORESTI, F. and PORTO-FORESTI, F., 2008. First reporto f a B chromosome in a natural population Astyanax altiparanae (Characiformes, Characidae). Genetics and Molecular Biology, vol. 31, no. 1(Suppl.), pp. 275-278.

KANTEK, D.L.Z., NOLETO, R.B., FENOCCHIO, A.S. and CESTARI, M.M., 2007. Cytotaxonomy, heterochromatic polymorphism and natural triploidy of a species of Astyanax (Pisces, Characidae) endemic to the Iguaçu River basin. Brazilian Archives of Biology and Technology, vol. 50, no. 1, pp. 67-74. http://dx.doi.org/10.1590/S1516-89132007000100008.

KAVALCO, K.L. and MOREIRA-FILHO, O., 2003. Cytogenetical analyses in four species of the genus Astyanax (Pisces, Characidae) from Paraíba do Sul River Basin. Caryologia, vol. 56, no. 4, pp. 453-461. http://dx.doi.org/10.1080/00087114.2003.10589358.

KAVALCO, K.F., PAZZA, R., BRANDÃO, K.O., GARCIA, L.F. and ALMEIDA-TOLEDO, L.F., 2011. Comparative cytogenetics and molecular phylogeography in the group Astyanax altiparanae - Astyanax aff. bimaculatus (Teleostei, Characidae). Cytogenetic and Genome Research, vol. 134, no. 2, pp. 108-119. http://dx.doi. org/10.1159/000325539. PMid:21447941.

LEVAN, A., FREDGA, K. and SANDBERG, A.A., 1964. Nomenclature for centromeric position on chromosomes. Hereditas, vol. 52, no. 2, pp. 201-220. http://dx.doi.org/10.1111/j.1601-5223.1964. tb01953.x.

LIMA, F.C.T., MALABARBA, L.R., BUCKUP, P.A., SILVA, J.F.P., VARI, R.P., HAROLD, A., BENINE, R., OYAKAWA, O.T., PAVANELLI, C.S. and MENEZES, N.A., 2003. Genera Incertae Sedis in Characidae. In: R.E. REIS; S.O. KULLANDER; J.R. FERRARIS, eds. Check list of the freshwater fishes of South and Central America. Porto Alegre: Edipucrs, pp. 106-169.

LUCENA, C.A.S., 1993. Estudo filogenético da família Characidae com uma discussão dos grupos naturais propostos (Teleostei, Ostariophysi, Characiformes). São Paulo: Instituto de Biociências, Universidade de São Paulo. Tese de Doutorado em Ciências Biológicas.

LUI, R.L., BLANCO, D.R., MARGARIDO, V.P. and MOREIRAFILHO, O., 2009. First description of B chromosomes in the family Auchenipteridae, Parauchenipterus galeatus (Siluriformes) of the São Francisco River basin (MG, Brazil). Micron (Oxford, England), vol. 40, no. 5-6, pp. 552-559. http://dx.doi.org/10.1016/j. micron.2009.03.004. PMid:19394233.

MAISTRO, E.L., OLIVEIRA, C. and FORESTI, F., 2001. Cytogenetic characterization of a supernumerary chromosome segment and of B-chromosomes in Astyanax scabripinnis (Teleostei, Characidae). Genetica, vol. 110, no. 2, pp. 177-183. http://dx.doi.org/10.1023/A:1017961411614. PMid:11678508.

MALACRIDA, A.C.C.P., DIAS, A.L. and GIULIANO-CAETANO, L., 2003. Natural triploidy in Astyanax aff. scabripinnis (Pisces, Characidae) of the Tibagi river bay-PR. Cytologia, vol. 68, no. 3, pp. 267-270. http://dx.doi.org/10.1508/cytologia.68.267.

MARTINEZ, E.R.M., ALVES, A.L., SILVEIRA, S.M., FORESTI, F. and OLIVEIRA, C., 2012. Cytogenetic analysis in the incertae sedis species Astyanax altiparanae Garutti and Britzki, 2000 and Hyphessobrycon eques Steindachner, 1882 (Characiformes, Characidae) from the upper Paraná river basin. Comparative Cytogenetics, vol. 6, no. 1, pp. 41-51. http://dx.doi.org/10.3897/ compcytogen.v6i1.1873. PMid:24260651.

MESTRINER, C.A., GALETTI, P.M., VALENTINI, S.R., RUIZ, I.R.G., ABEL, L.D.S., MOREIRA-FILHO, O. and CAMACHO, J.P.M., 2000. Structural and functional evidence that a B chromosome in the characid fish Astyanax scabripinnis is an isochromosome. Heredity, vol. 85, no. 1, pp. 1-9.

MIRANDE, J.M., 2010. Phylogeny of the family Characidae (Teleostei: Characiformes): from characters to taxonomy. Neotropical Ichthyology, vol. 8, no. 3, pp. 385-568.

MOREIRA-FILHO, O. and BERTOLLO, L.A.C., 1991. Astyanax scabripinnis (Pisces; Characidae): a "species complex". Revista Brasileira de Genetica, vol. 14, pp. 331-357.

MOREIRA-FILHO, O., GALETTI JUNIOR, P.M. and BERTOLLO, L.A.C., 2004. B chromosomes in the fish Astyanax scabripinnis (Characidae, Tetragonopterinae): An overview in natural populations. Cytogenetic and Genome Research, vol. 106, no. 2-4, pp. 230-234. http://dx.doi.org/10.1159/000079292. PMid:15292596.

NÉO, D.M., BERTOLLO, L.A.C. and MOREIRA-FILHO, O., 2000. Morphological differentiation and possible origin of $\mathrm{B}$ chromosomes in natural Brazilian population of Astyanax scabripinnis (PISCES, CHARACIDAE). Genetica, vol. 108, no. 3, pp. 211-215. http://dx.doi.org/10.1023/A:1004157901097. PMid:11294607.

NELSON, J.S., 2006. Fishes of the world. 4th ed. New York: Wiley.

PACHECO, R.B., ROSA, R., GIULIANO-CAETANO, L., JÚLIOJÚNIOR, H.F. and DIAS, A.L., 2011. Cytogenetic comparison between two allopatric populations of Astyanax altiparanae Garutti et Britski, 2000 (Teleostei, Characidae), with emphasis on the localization of $18 \mathrm{~S}$ and $5 \mathrm{~S}$ rDNA. Comparative Cytogenetics, vol. 5, no. 3, pp. 237-246. http://dx.doi.org/10.3897/compcytogen. v5i3.1235. PMid:24260632.

PAMPONET, V.C., CARNEIRO, P.L., AFFONSO, P.R., MIRANDA, V.S., SILVA JUNIOR, J.C., OLIVEIRA, C.G. and GAIOTTO, F.A., 2008. A multi-approach analysis of the genetic diversity in populations of Astyanax aff. bimaculatus Linnaeus, 1758 (Teleostei: Characidae) from Northeastern Brazil. Neotropical Ichthyology, vol. 6, no. 4, pp. 621-630. http://dx.doi.org/10.1590/ S1679-62252008000400010.

PAZZA, R., KAVALCO, K.F. and BERTOLLO, L.A.C., 2006. Chromosome polymorphism in Astyanax fasciatus (Teleostei,Characidae). 1. Karyotypic analysis, Ag-NORs and mapping of the $18 \mathrm{~S}$ and $5 \mathrm{~S}$ ribosomal genes in sympatric karyotypes and their possible hybrid forms. Cytogenetic and Genome Research, vol. 112, no. 3-4, pp. 313-319. http://dx.doi. org/10.1159/000089886. PMid:16484788.

PERES, W.A.M., BUCKUP, P.A., KANTEK, D.L.Z., BERTOLLO, L.A.C. and MOREIRA-FILHO, O., 2009. Chromosomal evidence of downstream dispersal of Astyanax fasciatus (Characiformes, Characidae) associated with river shed interconnection. Genetica, vol. 137, no. 3, pp. 305-311. http://dx.doi.org/10.1007/s10709009-9389-4. PMid:19641999.

PERES, W.A.M., BUCKUP, P.A., BLANCO, D.R., KANTEK, D.L.Z. and MOREIRA-FILHO, O., 2011. Invasion, dispersion and hybridization of fish associated to river transposition: karyotypic evidence in Astyanax "bimaculatus group" (Characiformes: Characidae). Reviews in Fish Biology and Fisheries, vol. 1, pp. 1-8. 
PINKEL, D., STRAUME, T. and GRAY, J.W., 1986. Cytogenetic analysis using quantitative, high-sensitivity, fluorescence hybridization. Proceedings of the National Academy of Sciences of the United States of America, vol. 83, no. 9, pp. 2934-2938. http://dx.doi.org/10.1073/pnas.83.9.2934. PMid:3458254.

SALVADOR, L.B. and MOREIRA-FILHO, O. (1992). B chromosomes in Astyanax scabripinnis (Pisces, Characidae). Heredity, vol. 69, pp. 50-56.

SANTOS, N.M., FERREIRA-NETO, M., ARTONI, R.F., VICARI, M.R., BAKKALI, M., OLIVEIRA, C. and FORESTI, F., 2012. A comparative structural cytogenetic study in three allopatric populations of Astyanax scabripinnis (Teleostei: Characidae). Zoologia, vol. 29, no. 2, pp. 159-166.

SOUZA, I.L., VENERE, P.C. and MOREIRA-FILHO, O., 2007. Constitutive Heterochromatin and Ag-NOR polymorphism in the small characid fish Astyanax scabripinnis (Jenyns, 1842). Cytologia, vol. 72, no. 1, pp. 63-69. http://dx.doi.org/10.1508/ cytologia.72.63.
SUMNER, A.T., 1972. A simple techique for demonstrating centromeric heterocromation. Exptl. Cell Res. Research, vol. 75, no. 1, pp. 304-306. http://dx.doi.org/10.1016/0014-4827(72)90558-7.

VICARI, M.R., NOLETO, R.B., ARTONI, R.F., MOREIRA-FILHO, O. and BERTOLLO, L.A.C., 2008. Comparative cytogenetics among species of the Astyanax scabripinnis complex. Evolutionary and biogeographical inferences. Genetics and Molecular Biology, vol. 31 , no. 1, pp. 173-179.

VICARI, M.R., PISTUNE, H.F.M., CASTRO, J.P., ALMEIDA, M.C., BERTOLLO, L.A.C., MOREIRA-FILHO, O., CAMACHO, J.P. and ARTONI, R.F., 2011. New insights on the origin of B chromosomes in Astyanax scabripinnis obtained by chromosome painting and FISH. Genetica, vol. 139, no. 8, pp. 1073-1081. http://dx.doi.org/10.1007/s10709-011-9611-z. PMid:21948070.

VOLFF, J.N., 2005. Genome evolution and biodiversity in teleost fish. Heredity, vol. 94, no. 3, pp. 280-294. http://dx.doi. org/10.1038/sj.hdy.6800635. PMid:15674378. 